\title{
Os Obstáculos à Integração de Economias Desiguais. O Caso do Mercosul*
}

\author{
Bouzid Izerrougene ${ }^{* *}$
}

Resumo: 0 artigo busca examinar a tese de que as externalidades que resultam da integração econômica aumentam o investimento e a renda, diversificam a demanda e elevam as exportações de variedades dos mesmos produtos, estimulando a especialização intraindustrial. Deduz-se que a importância dos fluxos intraindustriais corresponde ao grau de convergência nos níveis de desenvolvimento entre as economias integradas. Ora, com a hipótese de convergência condicional, apenas os países que reúnem certas características comuns podem homogeneizar os seus níveis de desenvolvimento via mercado. Sendo assim, na ausência de programas de promoção de oportunidades de desenvolvimento, as grandes disparidades econômicas entre os países do Mercosul tendem a representar para os mais pobres um ônus permanente e cumulativo que pode ampliar a liderança das economias mais fortes e embaraçar o processo de integração.

Palavras-chave: Integração, Abertura Comercial, Comércio Intraindustrial, Niveis de Desenvolvimento, Mercosul, Bem-Estar.

Abstract: This paper attempts to examine the thesis that externalities which result from economic integration increase investment and revenue, diversify the demand and raise the exportations, inducing intraindustrial specialization, The intraindustrial flows correspond to a degree of convergence among development levels of integrated economies. Nevertheless, adopting the conditional convergence hypothesis, only the countries witch present some commons characteristics can homogenize their development levels through market. In such case, in the absence of programs development opportunities, the large economic assimetries among Mercosur's countries tend to represent for the poorer countries a permanent and cumulative onus that amplify the leadership of the more powerful economies and gets entangled to the integration process.

Keywords: Integration, Intraindustrial Trade, Free Trade, Development Levels, Mercosul, Welfare.

\footnotetext{
* Trabalho apresentado no Encontro União Européia - Mercosul, Universidade de Tours, França, março de 2006. O autor agradece particularmente à professora Maria Cristina Cacciamali, cujos pertinentes comentários permitiram reduzir as incongruências desse artigo.

** Doutor em economia pela universidade Paris-Villetaneuse, Professor no Curso de Mestrado de Economia da Ufba. E-mail: bouzid@ufba.br. Recebido em 20/10/06 e aceito em 10/12/07.
} 


\section{Introdução}

O conceito de integração econômica envolve, conjuntamente, a dimensão espontânea das relaçóes econômicas e a expressão explícita do interesse político. A integração econômica implica numa combinação complexa de oportunidades e riscos para cada parceiro. A avaliação das conveniências e ameaças não pode ser apenas de ordem contábil, aquela que se concentra nos efeitos contraditórios da queda das barreiras aduaneiras sobre a criação e o desvio de comércio. Ela deve levar em conta as mudanças estruturais que a integração econômica pode provocar nos fundamentos econômicos e sociais, tais como a acumulação do capital, a distribuição da renda, a natureza dos mercados, as regras contratuais e a reação dos agentes históricos. Assim, e em razão da complexidade dos fenômenos envolvidos e da sua imprevisibilidade, as prospectivas são necessariamente de ordem geral e devem recorrer ao auxílio da teoria a fim de detectar as principais tendências que se delineiam num horizonte assimilável. Os estudos empíricos são úteis, mas ainda não podem estabelecer um conjunto coerente de resultados de correlação entre as diferentes variáveis, pois, de um lado, divergem quanto à base de dados e técnicas econométricas utilizadas, além de apresentarem falhas metodológicas. De outro, ainda são raros os estudos econométricos que estimam o impacto da formação de áreas de livre comércio sobre o nível de bem estar ou sobre a disparidade de rendas.

$\mathrm{O}$ argumento principal que justifica a integração econômica se baseia na possibilidade de realizar economias externas, particularmente o potencial de ganhos em escalas de produção e de mercado para as empresas dos países integrados e para o investimento direto nos blocos econômicos. A dimensão regional pode servir de apoio aos projetos industriais de grande porte que, por sua vez, podem suscitar o desenvolvimento da tecnologia como fator importante para intensificar as malhas produtivas e reforçar o comércio intraindustrial ${ }^{1}$, mais lucrativo e sustentável do que o comércio intersetorial.

Esse artigo busca averiguar a veracidade dessas suposiçóes, à luz das teorias que prevêem efeitos da formação de áreas de comércio livre sobre o bem-estar dos países envolvidos. No caso do Mercosul (MS), restrito aqui

\footnotetext{
${ }^{1}$ As exportações e importações simultâneas de produtos pertencentes à mesma indústria.
} 
aos quatro primeiros sócios (Brasil, Argentina, Paraguai e Uruguai), tentase mostrar como é difícil, num processo que envolve atores cujo grau de desenvolvimento é muito desigual, haver uma distribuição equânime de ganhos e perdas, sem que houvesse uma política deliberada de redução das assimetrias entre os parceiros. As divergências são múltiplas e se encontram principalmente nas dimensóes dos mercados nacionais, no estado da infraestrutura econômica e social, no acesso à tecnologia e ao crédito, nas normas jurídicas e nas políticas macroeconômicas.

Para alcançar e avaliar uma grande parte das suposições teóricas e empíricas a respeito das implicaçóes e condiçóes da formação de áreas de livre comércio, o trabalho será estruturado da seguinte forma: No segundo capítulo será feita uma leitura teórica que se refere às implicações da integração nos níveis de bem estar dos países sócios. No terceiro e quarto capítulo, serão discutidos os estímulos e condiçóes para o desenvolvimento de fluxos comerciais intraindustriais, assim como as características desses fluxos no âmbito do MS. O quinto capítulo será dedicado às condiçóes da convergência econômica, a qual seria um resultado da abertura aos fluxos de investimento internacional. Em seguida, num capítulo à parte, serão tratados os investimentos diretos no MS e sua implicação em termos de formação de capital na região. O sétimo e último capitulo será utilizado para discutir as assimetrias no MS e as possibilidades de reduzi-las a fim de facilitar a formação de capital na região. Algumas considerações gerais serão feitas no final.

\section{Integração e bem-estar - resenha teórica e metodológica}

Empiricamente, existem vários estudos que tentam comprovar os ganhos de abertura comercial ou de formação de áreas limitadas de livre comércio sobre as taxas de crescimento da renda. Mas, esses estudos ainda não conseguem superar as divergências metodológicas das bases de dados entre os países pesquisados e, também, não possuem ferramentas analíticas rigorosas e homogêneas para medir o grau da abertura ou da integração. Harrison utilizou o conceito de neutralidade para definir a abertura "ideal". Neutralidade significa que os incentivos são neutros en tre poupar uma unidade de moeda estrangeira através da substituição das importaçóes ou obter uma unidade de moeda estrangeira através das exportaçōes (HARRISON, 1996, 
p. 420-421). Porém, traduzir essa noção de neutralidade em indicadores que possam apreciar a orientação da política comercial de um país, ao longo do tempo, ou de um grupo de países por um dado instante de tempo, não é uma tarefa trivial.

Em geral, para contornar o problema, a literatura empírica se utiliza de indicadores unidimensionais (barreiras tarifárias e náo-tarifárias, volume de comércio e sua importância no Pib, preços relativos, e outros critérios subjetivos). Vale, no entanto, observar que tais critérios colocam os problemas da agregação que são inevitáveis quando é necessário unificar os dados e levam a subestimar ou superestimar as restrições ou liberalizações e seu efeitos. Tarifas em determinados setores inibem desproporcionalmente as importaçóes através de efeitos multiplicadores sem que o seu peso real seja revelado na média das tarifas em geral e pode ser subestimado. Para contornar esse problema, Corden calculou tarifas médias a partir das tarifas efetivas por setor, o que deu números mais próximos da verdadeira estrutura de proteção ou liberalização (CORDEN, 1971). Entretanto, a utilização desses indicadores é extremamente complexa e se limita aos países onde os dados são levantados e as médias, ponderadas, são disponíveis por diferentes períodos de tempo, facilitando as comparaçóes.

Os problemas metodológicos associados ao cômputo das barreiras nãotarifárias são ainda mais complexos, tanto das medidas de freqüência quanto de cobertura. $\mathrm{O}$ que ainda compromete a comparação entre países é que os critérios de análise não refletem necessariamente a orientação da política comercial, já que as mesmas também podem estar associadas às características geográficas, além de serem muito sensíveis aos choques macroeconômicos e às conjunturas internacionais.

Do ponto de vista teórico, pode-se dizer que Jacob Viner (1950) foi o primeiro a sistematizar a teoria da integração. Antes dele, as análises neoclássicas da integração econômica baseavam-se na teoria das vantagens comparativas, como em Haberler (1937) e Gregory (1921), e consideravam apenas os efeitos sobre a produção. Pensava-se que toda integração regional propiciava maior crescimento e maior renda a todos os países sócios. Nessa tradição analítica, os benefícios da formação de uma área de livre comércio decorrem essencialmente da redução dos custos de produção e do 
deslocamento do capital para os países onde esses custos estejam memores (FERREIRA, 1997).

Viner (1950) mostrou que uma uniáo aduaneira pode levar tanto a um aumento como a uma diminuição do bem estar dos países envolvidos, dependendo do saldo entre a criação de comércio e o desvio de comércio que decorrem de uma união (VINER, 1950). A criação de comércio resulta da deslocalização geográfica da produção de uma fonte com custos mais elevados para uma fonte com custos mais reduzidos, ao passo que o desvio de comércio se observa quando há deslocalização geográfica da produção de uma fonte com custos mais reduzidos para uma fonte com custos mais elevados. Evidentemente, haverá um ganho líquido de bem estar se o efeito desvio de comércio for inferior ao efeito criação.

Depois de Viner, economistas, como Meade (1955), Gehrels (1956), começaram a considerar os efeitos da integração econômica também sobre o consumo. A abolição das barreiras ao comércio entre países que formam uma união aduaneira implica um inevitável aumento de concorrência, na medida em que o mercado interno de cada um dos países passa a apresentar idênticas condiçóes de acesso para todas as empresas da união. Isso estimula a produtividade das empresas, permite a redução dos preços e, conseqüentemente, beneficia o consumo. Por seu turno, as mudanças nos padróes de consumo estimulam a inovação e a modernização, proporcionando surtos de investimento.

Nas últimas décadas, principalmente depois da formação da união européia, assistiu-se a uma profusão de estudos que buscam comprovar impactos positivos ou negativos da integração econômica. Muitos desses estudos se inspiram e se confundem com as teorias de comércio internacional e de desenvolvimento. Em muitos casos, os mesmos argumentos a favor ou contra a liberalização do comércio mundial são utilizados a favor ou contra a integração econômica regional. Contudo, enquanto a primeira estipula a remoção indiscriminatória das barreiras à movimentação dos fatores, a segunda tem como objetivo a imposição de direitos aduaneiros sujeitos à discriminação geográfica ${ }^{2}$. Surgiram modelos teóricos que estabelecem uma

\footnotetext{
${ }^{2} \mathrm{Ou}$ seja, existe discriminação geográfica quando uma mesma mercadoria está sujeita a diferentes taxas de importação, de acordo com o país de origem,
} 
relação tanto positiva quanto negativa da abertura comercial e da integração regional. Exemplos de modelos teóricos que prevêem um impacto positivo da abertura sobre a taxa de crescimento e o nível de renda são Lee (1993), Romer (1994), Mankiw, Romer e Weil (1992), Harrison (1996), Kenneth Rogoff (2002) e todos os defensores do chamado Consenso de Washington. Young (1991), em contraposição, mostra um impacto negativo do livre comércio sobre as taxas de crescimento. Modelos que geram efeitos ambíguos são: Grossman e Helpman (1990), Chuang (1998) e Rodríguez e Rodrik (1999).

Enquanto a análise de Viner (1950) se baseava nas teorias neoclássicas do comércio e do crescimento econômico, pressupondo a existência de concorrência perfeita e a ausência de custos de transporte, os estudos mais recentes tendem a explicar os efeitos da formação de áreas livres sobre o bem estar em geral pelo aproveitamento de economias de escala, da especialização, dos investimentos diretos e de outras conseqüências favoráveis. A análise deixou de se centrar nos efeitos estáticos de localização e de consumo que resultam, respectivamente, das vantagens comparativas e dos níveis de preço, e passou a enfocar os efeitos de longo prazo e dar ênfase à dinâmica dos fluxos internacionais e suas relaçóes com variáveis tais como: concorrência monopolista, economia de escala, decisóes de investimento, níveis de renda e comércio intraindústria.

Dentro dessa abordagem dinâmica, Frankel e Romer mostram que a formação de blocos econômicos pode ser benéfica quando os países membros introduzem produtos importados no interior do bloco, os quais irão permitir a redução de distorçóes nos modelos de consumo existentes; quando as economias de escala permitem a redução de preços ou, ainda, quando a nova concorrência reduz o poder do mercado ou dos monopólios nacionais ineficientes (FRANKEL, ROMER, 1996).

A formação de uma união aduaneira tem a possibilidade de aumentar os investimentos, como conseqüência da ampliação do mercado e da confiança dos investidores enquanto ao escoamento do produto e ao abastecimento em insumos. O nível de investimentos na união também é influenciado positivamente pelo interesse de produtores de países terceiros de operar 
dentro da uniáo aduaneira, visando tirar partido de um mercado amplo e evitar as tarifas comuns do bloco.

Uma união aduaneira pode induzir economias de escala que são susceptíveis de resultar tanto da fusão de empresas que o aumento da concorrência provoca, quanto da possibilidade de explorar um mercado que a integraçáo torna maior. Com efeito, a remoção de barreiras ao comércio entre países provoca um aumento de transaçóes que estimula a especializaçáo e que pode se traduzir por ganhos mútuos. A abertura dos mercados nacionais pode melhorar a alocação dos fatores de produção e favorecer a produtividade. A resultante elevação de renda tende a aumentar e diversificar a demanda e tornar a estrutura produtiva mais diversificada. A diversificação estimula o comércio intraindustrial em que os lucros, mais elevados do que no comércio intersetorial, conduzem os países a uma maior especialização. Uma forte proporção de comércio intraindustrial corresponderia, portanto, a ganhos de escala e competitividade, à diversificação da demanda, ao fortalecimento da concorrência, à elevação da renda e à difusão da tecnologia ${ }^{3}$

Todavia, a natureza e a amplitude dos resultados referidos são relativamente ambíguas, principalmente por náo considerar a questão da repartição dos ganhos e perdas entre os sócios. Mesmo que se imagine que os tratados de integração formalizados nos últimos anos contribuam para o aumento do bem-estar das populaçóes envolvidas, os resultados da integração não são os mesmos para os diferentes sócios. De fato, à medida que a integração se completa, a modificação obrigatória da estrutura dos preços relativos provoca uma especialização dos países na produção de bens e serviços para os quais possuem vantagens em termos de escala e de tecnologia, colocando dúvidas quanto às possibilidades de desenvolvimento nas economias carentes dessas vantagens. A falta de desenvolvimento impede a diversificação da demanda e restringe o comércio intraindustrial.

\footnotetext{
${ }^{3}$ Para além dos efeitos referidos da integração e da formação de áreas de livre comércio sobre as economias envolvidas, há outros que lhes estão associados, notadamente as alterações introduzidas nas instituições a fim de resolver problemas de coordenação e eliminar obstáculos à cooperação. Há ainda outros fatores políticos e culturais que são de grande importância para os processos de integração regional e que devem merecer destaque para se compreender a importância da integração econômica e suas incidências sobre o bem estar das populações incluídas ou excluídas.
} 


\section{Integração e comércio intraindustrial}

As economias de escala, a diferenciação da oferta e a concorrência imperfeita estâo na origem dos fluxos de bens e serviços entre economias homogêneas em termos de desenvolvimento, produtividade e preferência dos consumidores, enquanto as vantagens comparativas fatoriais e estáticas continuam a explicar o comércio intersetorial entre países desigualmente desenvolvidos. No primeiro tipo de comércio, o intraindustrial, os ganhos são fundamentalmente o fruto das estratégias empresariais quanto à ampliação dos mercados e à diferenciação dos produtos. No segundo tipo, a realocação dos recursos entre as indústrias é definida pela busca de ganhos de eficiência que derivam da especialização nas atividades que utilizam os fatores mais disponíveis nas economias nacionais.

Antes da década de noventa, o comércio intraindustrial era mais observado entre os países ricos, em que os níveis de desenvolvimento são comparáveis. Nos anos mais recentes, com o crescimento dos investimentos diretos nos países periféricos, os fluxos intraindustriais começaram a mostrar tendência ao crescimento entre economias com níveis desiguais de desenvolvimento. E, na perspectiva de avanços nos processos de integração econômica, o comércio intraindustrial aumentaria a sua importância tanto entre os países ricos como entre os menos desenvolvidos. Em muitos países não desenvolvidos as exportações não se limitam mais ao comércio intersetorial, de produtos diferentes e complementares, mas abrangem também gamas de qualidade de produtos substituíveis e concorrenciais. Essa nova realidade suscitou a construção de modelos teóricos de comércio internacional que permitem superar a dicotomia original entre complementaridade e concorrência, abrindo espaço para uma nova visão em que os benefícios de ambos os tipos de comércio se articulam e se reforçam para criar motivos para o comércio.

A tradicional teoria das vantagens comparativas comporta a idéia subjacente de que a intensidade na utilização do capital aumenta com a melhoria do produto, o que manteria as vantagens comparativas estáticas como fator explicativo do comércio intraindustrial. A especializaçáo industrial ocorre através de uma relação positiva entre a composição do capital e a qualidade do produto exportado. A especialização intraindustrial, precisamente, provoca movimentos de reestruturação cujos efeitos sobre a 
composição fatorial dos produtos não são neutros. $\mathrm{O}$ reconhecimento dessa realidade levou os modelos teóricos a operar uma divisão complexa entre os fluxos intraindustriais verticais, que designam as transaçóes de bens similares, mas com qualidades diferentes, e os fluxos intraindustriais horizontais, que se referem ao intercâmbio de produtos também similares e de qualidades diferentes, mas diferenciados por características e atributos secundários ${ }^{4}$. Enquanto o comércio horizontal é motivado pelas vantagens competitivas associadas à inovação, o comércio intraindustrial vertical é explicado pelas vantagens comparativas, resultantes da dotação fatorial ${ }^{5}$. Todavia, uma especialização na base da diferenciação vertical pode passar por processos contínuos de ajustamentos quando os fatores de produção são específicos e as variedades de produto intensivas em capital e/ou em mão-de-obra qualificada (HARFI, MONTET, OULMANE, 1997).

Os modelos baseados na corrente de Geografia Econômica, como o de Krugmann (1991), de Venables (1996) e de Lipietz e Benko (1994) supóem que as economias de escala aumentam com o a elevaçáo da qualidade dos produtos, sobretudo porque os custos fixos de sua fabricação são mais elevados. Nessa ótica, na medida em que as economias de escala se tornam mais importantes, as exportaçóes de variedades dos mesmos produtos de alta tecnologia se elevam e evoluem para a especialização intraindustrial horizontal. As externalidades podem ser estimuladas pela integração econômica que, ademais, reduz a importância das relações de aglomeração, uma vez que as firmas podem comprar bens intermediários no exterior e exportar boa parte da sua produção. Isso permitiria uma forte densidade territorial das empresas e dos consumidores, conforme as vantagens competitivas de cada país ou bloco de países. A especialização industrial estaria então estimulada pelo comércio intraindustrial. (FUJITA, KRUGMANN, VENABLES, 1999).

Outrossim, o comércio intraindustrial é associado ao nível de renda per capita, cuja elevação tende a reforçar e diversificar a demanda.

\footnotetext{
${ }^{4}$ A metodologia para diferenciar ambos os tipos de comércio, sugerida por Greenaway, Hine, Milner (1995), consiste em comparar o valor unitário na exportação do produto com o valor na importação do mesmo produto. A idéia subjacente a essa metodologia é que os preços são um bom indicador de qualidade.

${ }^{5}$ A vantagem comparativa de um país ou uma empresa define os setores / produtores onde a inserção no comércio internacional é mais eficiente em termos de alocação de seus fatores de produção. Quanto à vantagem competitiva, a sua origem é, segundo Porter (1990), o valor que a empresa cria para seus clientes em excesso ao custo que tem para criá-lo. A vantagem competitiva é construída pelas empresas no seu esforço de inovar.
} 
Conseqüentemente, o intercâmbio será mais denso quando os países integrados possuem níveis de renda e estruturas de demanda similares. Nessas condiçóes, pela tendência à convergência econômica e social dos países parceiros, a integração aumenta as escalas de produção e facilita o incremento da competitividade, vista como a capacidade em melhorar e sustentar a participação nos mercados globais.

Todavia, mesmo que a especialização intraindustrial multiplique as gamas de produtos e aumente a qualidade, o seu processo pode se esbarrar em dois efeitos possíveis. O primeiro é o da polarização dos investimentos, cuja própria dinâmica se apóia nas economias de escala (KRUGMAN, 1991) e em virtude do qual o caráter mútuo dos ganhos de comércio pode ser reduzido, em razão da concentração das atividades, particularmente as de alta tecnologia, nas regióes munidas em economias de escala (BRÜLHART, 1995) e em níveis mais elevados de renda. A malha produtiva condiciona a reação das indústrias nacionais ao processo de integração. Se a estrutura industrial for débil, o intercâmbio será mais intersetorial do que intraindustrial, o que minimizaria seriamente a dinâmica do comércio.

O segundo efeito que dificulta a especializaçáo intraindustrial diz respeito ao crescente preço de demanda, em razão do custo crescente de diferenciação. Quando os rendimentos de escala aumentam, a remuneração dos fatores aumenta também e, com ela, a demanda cresce. A capacidade empresarial de adaptar a estrutura produtiva a esse perfil mutante da demanda condiciona a competitividade na economia e configura a natureza da especialização intraindustrial. O grande desafio para o produtor, nesse caso, é poder flexibilizar ao máximo a organização da produção, em conformidade com as mudanças no mercado. Chega-se ao longo desse processo a produzir para atender encomendas, conferindo à demanda um caráter dinamizador. Aí, qualquer intervenção sobre o mercado implicaria custos crescentes, associados não somente à junção de acessórios e utilidades aos produtos, como, também, a campanhas de publicidade, que somente as grandes empresas são capazes de suportar.

Uma das incoerências dos modelos de diferenciação está na hipótese de que cada empresa produz uma só variedade do produto (KRUGMAN, 1987; LANCASTER, 1978). Na verdade, como o número de firmas que 
podem realizar economias de escala é necessariamente limitado, essas firmas produzem um grande número de bens e variedades de produtos, beneficiandose de economias de escopo. Convém distinguir, então, os custos de produção que são comuns a todos os produtos ofertados, dos custos de diferenciação que são, por definição, específicos a cada gama de bens. Os dois custos são de natureza diferente: os custos comuns de produção são passíveis de economias de escala, enquanto os de diferenciação crescem com o número de variedades ofertadas. Os custos crescentes de diferenciação encarecem os produtos e reduzem o consumo.

Uma outra hipótese dos modelos de diferenciação é a do custo nulo para entrada de novas empresas no mercado. Não é difícil observar que esses custos existem, mesmo que alguns fatores, como a simplificação da tecnologia e a revolução das comunicaçóes, tendem a reduzi-los. Os custos de entrada conferem uma margem de manobra tal para os insiders que pode dissuadir os outsiders. Para manter essa vantagem, os primeiros são incentivados a sempre fabricar novas variedades, o que eleva os custos dos novos produtos e encarece o seu consumo.

Se a integração econômica amplia a demanda e aumenta o lucro, novos entrantes serão estimulados a produzir novas variedades, pelo menos até o momento em que o lucro se contrai. No estado de equilíbrio global, cada variedade de produto é produzida num só país e vendida em todos. Qualquer um pode produzir novas variedades, mas o número de variedades pode aumentar sem necessariamente provocar uma elevação no nível da produção total, inviabilizando com isso a realização de economias de escala. Simultaneamente, a multiplicidade extrema de variedades dos mesmos produtos reduz a sua singularidade e obriga a empresa a investir cada vez mais para radicalizar a diferenciação de seus produtos.

Em síntese, pode-se afirmar que inúmeros estudos tentaram identificar os fatores que predominam na determinação do comércio intraindustrial. Em geral, eles confirmam a hipótese de Markusen e Venables (1995), segundo a qual a importância desses fluxos corresponde ao grau de convergência nos níveis de desenvolvimento entre as economias parceiras. Isso é também confirmado pelos Modelos Gravitacionais que testam a relação entre o 
intercâmbio intraindustrial e os níveis de renda ${ }^{6}$. A proximidade geográfica é uma outra variável que motiva o comércio intraindustrial e configura a natureza da especialização. A integração formal, embora possa acentuar as tendências de especialização, não aparece nesses estudos como fator primordial para os fluxos intraindustriais ${ }^{7}$.

\section{O comércio intraindustrial do MS: limitado e concentrado}

O Mercosul adquiriu seus traços fundamentais no Encontro de Ouro Preto, em dezembro de 1994. Os países membros optaram por um modelo intergovernamental de gestão, em que as posiçôes comuns ficam subordinadas à vontade própria de cada estado nacional. $\mathrm{O}$ mercado comum previsto pelo Tratado de Assunção em 1991 ainda não se consolidou. Embora a grande maioria dos bens comercializados entre os países do MS não esteja mais sujeita a tarifas, os mercados nacionais ainda não estão totalmente livres das barreiras aduaneiras, e a união alfandegária via tarifas externas comuns (TEC) não se generalizou. $\mathrm{O}$ número excessivo de exceçóes concedidas deturpa $\mathrm{o}$ processo de unificação.

Os resultados observados desde o final de 2003 mostram que os países do MS conseguem retomar a trajetória do crescimento de suas exportaçóes tanto dentro da região como para o exterior. A taxa de crescimento das exportaçóes em geral do MS passou de 0,5\% em 2002 para 19,2\% em 2003, 25,8\% em 2004 e 21,1\% em 2005 (CEPAL, 2007). Quanto às exportaçóes intra-MS, a sua trajetória de queda também foi interrompida no ano de 2003, quando a taxa de crescimento passou de $-33,3 \%$ para $24,6 \%$ nos anos referidos, realizando uma mudança de mais de 75 pontos percentuais! De 2003 até 2006, as exportaçóes dentro do bloco foram crescendo de forma elevada, em torno de $25 \%$ na média anual, segundo os dados da Cepal. Os países do MS como todo, também, inverteram, a partir do mesmo ano, a sua posição de déficit na balança comercial vis a vis do mundo e passaram a realizar superávits crescentes, sem, para tanto recorrer, como tradicionalmente, ao artifício da desvalorização cambial. Isso mostra que, à primeira vista, a dinamização do MS não provocou grandes efeitos de desvio de comércio, ainda mais quando

\footnotetext{
${ }^{6}$ Para o Mercosul especificamente, ver Sá Porto (2002).

${ }^{7}$ Ver Freenstra, Markusen, Rose (2000).
} 
são as exportaçóes de produtos industrializados que registram a maior taxa de crescimento dos últimos anos.

Porém, essas exportaçóes se concentram nos bens intermediários (60\% das exportaçóes), são de baixo valor unitário, agregam pouco valor ${ }^{8}$ e sua competitividade deriva essencialmente das vantagens em recursos naturais. A participação dos produtos primários nas exportaçóes do MS é de $58 \%$, entre 1999 e 2001 (KUWAYAMA, DURAN LIMA, 2003), o que pode perpetuar as ameaças de deterioraçáo dos termos cambiais, embora, na conjuntura atual, devido essencialmente à forte demanda asiática, os preços das commodities encontrem-se bastante elevados?

Portanto, mesmo que a indústria acuse um aumento na sua participação no total, os modos de especializaçáo na região não mudaram muito, apesar da abertura comercial e das estratégias de integração, realizando-se na base da exportação de bens tradicionais, intensivos em recursos naturais. Essa maior importância da indústria de transformação nas exportações ainda não é suficiente para inverter os déficits no comércio de bens industrializados da região, particularmente naqueles de alto conteúdo tecnológico. A região como todo ainda depende dos excedentes do setor primário para financiar o investimento industrial. Devido a essa rigidez na pauta de exportaçóes, os países do Cone Sul permanecem vulneráveis às oscilações nos preços relativos internacionais e não se inserem suficientemente nas redes globalizadas de produção.

Essa dependência não se manifesta atualmente de maneira visível como isso ocorre tradicionalmente, em virtude do recente ciclo de crescimento dos preços das matérias primas, puxados pela forte demanda chinesa. No entanto, esse fenômeno traz várias dúvidas a respeito da sua duração, num cenário de fortes desequilíbrios internacionais que são provocados pelos profundos déficits americanos e pela própria tendência do aumento dos preços das commodities e das conseqüentes corridas especulativas e riscos de inflação. Existe o temor de que a perpetuação do esquema atual de preços elevados provoque uma especialização na exploração dos produtos naturais e acentue o movimento de desindustrialização na regiâo. Há um risco sério de que a

${ }^{8}$ Vale lembrar que a agregação de valor traz consigo o problema do escalonamento tarifário.

${ }^{9}$ Os termos cambiais da América Latina cresceram 3,3\%, na comparação dos níveis médios da década de 1990 com os níveis de 2006 (KOSAKOFF, CAMPANARIO, 2007). 
apreciação cambial, causada pela valorização das commodities, prejudique a indústria na região e leve ao estabelecimento de uma divisão de trabalho, em que a China se especialize em manufaturados e a região em produtos intensivos em recursos naturais ${ }^{10}$.

Nessa situação, a integração regional poderia representar uma alternativa para melhorar a qualidade das exportaçóes, gerar uma capacidade em formar novas vantagens competitivas e superar a tradicional divisão internacional do trabalho. A inserção desejada na economia internacional é a que se faz pelo intercâmbio intraindustrial, de produtos diferenciados e com elevado valor agregado. Mas, a concentração desse tipo de especialização nos países mais avançados perpetua as condiçôes de intercâmbio desigual e as reproduz dentro mesmo de mercados comuns formados por países não desenvolvidos.

$\mathrm{O}$ comércio intraindustrial do MS com o resto do mundo registrou, segundo as informaçóes da Abceb, um crescimento considerável nos últimos anos, passando de 6\% a 11\% das exportaçóes do bloco entre 1990 e 2004 . Porém, a sua participação no mercado mundial permanece inexpressiva, pois esse tipo de comércio vem aumentando no mundo com maior intensidade. No Brasil, onde as exportaçóes de industrializados são as mais diversificadas de todos os países do MS, o índice Gruber \& Lloyd $^{11}$ do comércio intraindustrial extra-MS é de 0,41 em $2003^{12}$ (ABCEB, 2006).

A maior parte das exportações intraindustriais dos países do MS é realizada no próprio comércio intrabloco, com $54 \%$ do total ${ }^{13}$. Neste total, predominam os bens verticalmente diferenciados, e, dele, $95 \%$ são concentrados nas transações entre Brasil e Argentina. Os dois países mostram os mais elevados índices Gruber \& Lloyd do comércio regional, de 0,3 e 0,27\% respectivamente. $\mathrm{O}$ índice Gruber \& Lloyd do comércio intraindustrial entre Brasil e Argentina passou de 0,22 para 0,61, entre 1990 e 2002. A proporção

\footnotetext{
${ }^{10}$ Esse risco é conhecido na literatura como enfermidade holandesa ou Dutch desease.

${ }^{11}$ É o indicador mais utilizado para medir a importância do comercio intraindústria. Baseia-se no grau da justaposição dos fluxos comerciais (trade overlap) a nível de uma indústria. $O$ índice varia de 0 a 1 , respectivamente indicando ausência total de comércio intraindustrial e sua existência exclusiva. Está assim definido: $G L_{k}=\frac{\sum_{i}^{1}\left(X_{i k}-M_{i k}-\left|X_{i k}-M_{i k}\right|\right)}{X_{k}+M_{k}}$ onde $X_{i k}$ são as exportações da indústria i para o pais $\mathrm{k}$; $\mathrm{M}_{\mathrm{ik}}$ são as importações da indústria i do país k; e $\mathrm{X}_{\mathrm{k}}$ e $\mathrm{M}_{\mathrm{k}}$ são as exportações e importações industriais para e do país $\mathrm{k}$.

${ }^{12} \mathrm{~A}$ título de comparação esse índice é de 0,65 no conjunto dos países da União Européia..

${ }^{13}$ Os Estados Unidos e o Canadá participam com 26\% e a União Européia, 15\%.
} 
do comércio intraindustrial vertical entre Brasil e Argentina passou de 22,2\% para 52\%, entre 1990 e 2001 e a do comércio intraindustrial horizontal, de $5,3 \%$ para $18 \%$ no mesmo período (UNCTAD, 2005). Trata-se, a priori, de um comércio intraindustrial total que é típico entre dois países limítrofes e com níveis comparáveis de desenvolvimento, duas características que definem a nova dinâmica do comércio internacional.

No entanto, ao utilizar um indicador que pondere os desequilíbrios comerciais no MS, a evolução dos índices de comércio intraindustrial entre Brasil e Argentina fica menos acentuada, mesmo quea tendência ao crescimento se confirme. De fato, a agregação demasiada na nomenclatura dos produtos e segmentos superestima a importância do comércio intraindustrial entre os dois países. Um exemplo dessa agregação inapropriada está na agroindústria. O elevado índice de comércio para este segmento se explica principalmente pelo comportamento de ramos como "carnes", "conservas vegetais" e "outros produtos agrícolas”. Ora, não é possível evocar uma expansão de intercâmbio de produtos similares para ramos que sugerem uma grande diversidade na sua composiçáa. Os produtos desses agrupamentos não são necessariamente substituíveis. Uma desagregação maior teria certamente reduzido o surto revelado nas transações intraindústriais.

A análise setorial mostra que o intercâmbio intraindustrial no MS está particularmente concentrado na química e na indústria automobilística ${ }^{14}$, dois setores controlados pelo capital estrangeiro. Aliás, por uma grande parte, as exportaçóes da regiáo não são o resultado de estratégias próprias às economias regionais, mas, sim, o subproduto das políticas comerciais das firmas multinacionais (MIOTTI, QUENAN, VINOGRAD, 1998).

Nos demais setores e, também, nas transaçóes com Paraguai e Uruguai, a natureza do comércio é fundamentalmente interindustrial, essencialmente motivada por diferenças fatoriais. É somente através desses setores, como energia e agroindústria, cujo valor unitário é baixo, que os pequenos países, Paraguai e Uruguai, conseguem participar do comércio intrabloco. A integração econômica regional pode, a rigor, aprofundar nesses países os processos de transformação e alongar as cadeias de produção, mas não é,

\footnotetext{
${ }^{14}$ Uma parte importante do comércio intraindustrial entre Argentina e Brasil deve-se ao complexo automotivo, regido por acordos de preferência que vão além das questões estritamente tarifárias.
} 
evidentemente, essa especialização de base que garante a sustentabilidade das exportações. Evoluir da produção básica até a produção manufatureira, agregando valor aos bens básicos, não assegura necessariamente um avanço até as atividades de maior competitividade.

\section{Abertura comercial, investimento direto e convergência econômica}

$\mathrm{Na}$ doutrina neoliberal, uma vez que as normas jurídicas se harmonizam, o mercado se encarrega de reduzir as diferenças de progresso entre as diversas economias. Num regime de mercado livre, teoricamente, a corrido aos lucros levaria o capital internacional a investir nos países onde há escassez de capital, provocando uma tendência à equalização dos níveis de produtividade e do poder de compra entre as naçóes. Com a mobilidade do capital e das mercadorias, a alocação dos fatores se faria segundo os critérios de otimização das vantagens, estendendo o progresso para todos. A mobilidade do capital, da mesma forma que a expansão do comércio, sustentaria a produtividade, estimularia a especialização competitiva, aumentaria os ganhos multilaterais e provocaria uma tendência à convergência das economias.

Um dos primeiros teóricos a desenvolver argumentos a esse respeito foi Ohlin (1933), para quem os investimentos diretos externos são motivados principalmente pela possibilidade de obtenção de altas taxas de lucro em mercados em crescimento, facilitados pela possibilidade de financiamento a taxas de juros relativamente reduzidas no país de origem. $\mathrm{O}$ argumento original de Ohlin se situa no conceito de vantagens comparativas, segundo qual é mais benéfico para os países se especializarem no que produzem com mais eficiência para poder aumentar suas condiçóes de acesso aos outros produtos via importação. No entanto, se é verdade que a abertura comercial confere aos países menos desenvolvidos vantagens em termos de abastecimento em produtos de qualidade superior, a preços relativamente reduzidos, há ainda dúvidas quanto à capacidade de aumentar a produtividade com o auxílio do investimento direto, em setores potencialmente competitivos, de um modo suficiente para compensar as perdas que se devem ao abandono necessário de um grande número de setores não competitivos.

Hymer (1976) inaugurou uma nova tradição nos estudos sobre as firmas 
multinacionais (FM), mostrando que se estas conseguem competir com empresas locais que possuem maior conhecimento do mercado e do ambiente local, é porque apresentam vantagens compensatórias, como economia de escala, diferenciação produto, acesso privilegiado a financiamentos, monopólio de inovação, etc. Tendo alguma compensação positiva, a FM irá preferir atender ao mercado externo por meio de investimentos diretos ou licenciamentos da produção para empresas locais, em vez de exportaçóes. A escolha entre produzir localmente, exportar ou licenciar depende da natureza do mercado e das condiçóes de controle. Quando a firma não pode estender tanto a produção quanto o controle além do país de origem, ela exporta; quando pode produzir no exterior e controlar a partir do país de origem, ela licencia; e, finalmente, quando consegue produzir e controlar além das fronteiras nacionais, a firma efetua ID para realizar uma produção própria.

Ao analisar essas decisóes de intervenção internacional das firmas, Buckley e Ghauri (1991), enfatizaram a necessidade de minimizar pela internalização os custos de transação como motivo de ID. A ênfase da teoria da internalização se dá nos mercados de produtos intermediários e na formação de redes internacionais de produção.

Kindleberger (1969) e, depois, Caves (1971) observaram que os IDs ocorriam basicamente nos setores onde predomina a concorrência monopolista, deduzindo que é a natureza do mercado que determina as decisões de investir das FMs e não o inverso. Nessa mesma linha de explicação, encontram-se os trabalhos de Graham (2000), em que os IDs resultam da rivalidade entre empresas e da interação oligopolística. Eles crescem como forma de ocupar mercados e reduzir os riscos de concorrência. A existência de IDs relaciona-se ainda com as barreiras ao comércio ou então com as necessidade de garantir o fornecimento ou como forma de levantar barreiras a novas firmas no mercado externo.

O investimento direto e os fluxos de capital são organicamente articulados em torno das opçóes estratégicas das firmas multinacionais, as quais, de verdade, configuram a especialização dos países, num quadro de rivalidade oligopolista à escala mundial. Os fluxos comerciais não são motivados apenas pelas vantagens fatoriais e tecnológicos, mas também pelas estratégias de localização, cujos parâmetros orientam as decisões entre diferentes formas de 
abastecer o mundo. Essas decisões são sinônimo de grandes movimentos de capital e exercem forte pressão sobre as políticas domesticas.

As empresas transnacionais perfazem $66 \%$ das exportaçóes mundiais e, deste total, 58\% são operações intrafirma. Em muitos países respondem pela maior parte das transaçóes internacionais ${ }^{15}$. Essa importância se deve não somente à dimensão dos bens e serviços trocados, mas também ao poder das multinacionais de criar novos fluxos de bens e de capitais entre as unidades de uma mesma empresa (LACERDA, 2004).

Os estudiosos da firma multinacional se dividem, em geral, entre os que concebem os movimentos de capitais e os fluxos de bens e serviços como transaçóes complementares, e aqueles que se inspiram do teorema de Mundell (1957), considerando-os exclusivos. As análises realizadas sob a égide desta corrente exclusivista mostram que nos países que dispóem da mesma tecnologia, os movimentos de capital e as transaçóes comerciais se substituem. As outras análises explicam que há complementaridade quando as empresas desses países buscam explorar fatores menos custosos no estrangeiro para, em seguida, produzir e exportar ao resto do mundo. Baldwin (1984) argumenta que mesmo no caso em que os custos de produção são menos elevados nos países não desenvolvidos, as firmas preferem se localizar, a priori, nos centros desenvolvidos, a fim de beneficiar da proximidade dos mercados mais dinâmicos (IPEA, 2004).

Pode-se opinar que as novas tecnologias de informação e comunicação reforçam a tese da substituibilidade. A redução dos custos de transporte, a tendência à miniaturização dos produtos e a redução das barreiras comerciais permitem às empresas centralizar as dimensóes fundamentais do processo empresarial no núcleo matriz, a fim de explorar externalidades inovativas.

Contudo, a transferência de tecnologia pode se realizar independentemente dos investimentos diretos. As próprias mercadorias cambiadas no mercado internacional representam um forte veículo de transferência de tecnologia. Robert Mundell (1957) mostrou que o intercâmbio comercial é um meio para o intercâmbio de fatores de produção, posto que os bens trocados incorporem obrigatoriamente conteúdos produtivos (ciência, tecnologia, conceitos, etc.). Assim, pode-se considerar que a perfeita mobilidade

${ }^{15}$ Para entender a importância das transnacionais no mundo, ver Lacerda (2004). 
internacional das mercadorias leva aos mesmos resultados da perfeita mobilidade internacional dos fatores de produção: a homogeneização das condiçóes de produção e, conseqüentemente, o enfraquecimento do conceito de vantagens comparativas em benefício do fortalecimento do conceito de vantagens competitivas.

No modelo do diamante nacional de Porter (1990), as vantagens competitivas são construídas pelas firmas nos seus esforços de inovar, criando novos produtos, novos processos, novas marcas e promovendo melhoramentos. A inovação, segundo o autor, pode surgir em qualquer setor industrial, independentemente da disponibilidade dos fatores de produção, desde que existam condições que estimulem o esforço inovativo, tais como a densidade da malha produtiva, a importância da demanda, as estratégias empresariais e a estrutura do mercado.

Numa estrutura monopolista de mercado, a detenção exclusiva dos elementos formadores de vantagens competitivas pode se prolongar e até mesmo se perpetuar, pois as primeiras empresas ou países que produzem um determinado bem dificilmente serão alcançados, sobretudo quando utilizam tecnologias avançadas. As grandes firmas dos países líderes consigam monopolizar a inovaçáo, posto que antes do novo conhecimento atingir a periferia do sistema novos procedimentos ou novos produtos mais competitivos são descobertos. Em suma, as dificuldades à convergência das formas de produção ficam maiores quando, citando Porter, "a eficiência estática num ponto do tempo é rapidamente superada por um índice de progresso mais intenso" Porter (1990, p. 21).

As possibilidades de criação de riqueza dependem cada vez mais da possibilidade de dispor de tecnologias e informaçóes novas e em permanente renovação. Estas tecnologias e informaçóes são cada vez mais protegidas por direitos exclusivos. A conquista de posiçóes de mercado via produçóes que incorporam inovaçóes está associada a lucros diferenciais que, pelo seu caráter permanente, assumem a forma de renda tecnológica. Por essa razão, a desproporção tecnológica entre as economias tende a representar para os menos desenvolvidos um ônus permanente e cumulativo que amplia a liderança das economias mais fortes, porque capacitadas a reforçar sua vantagem inicial, sobretudo com o acesso ampliado a novos mercados. Esses 
aspectos cumulativos da trajetória tecnológica definem avanços tecnológicos futuros, em função da posição ocupada dentro da fronteira tecnológica; conferem vantagens absolutas aos possuidores do monopólio de inovaçóes e ganham destaque explicativo para os padróes de trocas, em detrimento de variáveis convencionais, como preço e câmbio.

Essa forma particular de vantagem absoluta pode ser limitada no tempo, posto que empresas localizadas em outras naçóes podem sempre reproduzir a inovação ou realizar uma semelhante, pondo um termo à posição de monopólio da primeira firma inovadora. Os fluxos de exportação oriundos desta firma tenderiam a diminuir ou até mesmo desaparecer, razão pela qual os países que desenvolvem estratégias pautadas em vantagens absolutas advogam a necessidade de um tratado de propriedade intelectual e industrial que assegure as patentes e com elas as rendas decorrentes do processo de inovação.

A idéia da restrição temporal do monopólio de inovação foi originalmente desenvolvida por Michael Posner (1961), para o qual o processo de difusão internacional das novas técnicas e novos produtos, ao erodir as vantagens absolutas, ajustando preços e custos, cria sustentabilidade para as trocas internacionais, baseando-as em vantagens comparativas. Nessa mesma linha de análise, Raymond Vernon (1966) desenvolveu a teoria do ciclo de vida do produto, onde as inovaçóes se explicam pelas características gerais do país onde aparecem. O produto passa por diferentes etapas: surgimento, crescimento, maturidade e envelhecimento. Essas fases são associadas ao crescimento da produção e podem ser caracterizadas pela evolução da demanda, pela evolução das técnicas de produção utilizadas em função da importância da demanda e da sua elasticidade-preço e, pelas modalidades de abastecimento nos mercados internacionais.

De acordo com esse modelo, como as inovaçôes são poupadoras de mãode-obra, elas surgem inicialmente nos países mais intensivos em capital e, depois, paulatinamente, se estendem para países menos intensivos em capital. Num primeiro momento, aparecem bens sofisticados ou de luxo, produzidos em pequena escala e direcionados exclusivamente para o mercado nacional. A difusão do novo produto implica na utilização de técnicas de produção de escala que levam, num segundo momento, a explorar mercados 
externos. Nessa nova fase, a firma inovadora irá produzir o bem ou licenciar sua produção em outros países, a fim de resistir à ameaça de concorrentes e ocupar mercados. Numa última etapa, o próprio mercado de origem passa a ser abastecido por importaçóes oriundas das filiais implantadas no exterior.

Vernon (1966) conclui que a vantagem de uma firma pode mudar simplesmente porque: a demanda não é estática, os produtos são submetidos a um ciclo de vida e as multinacionais deslocam a produção para outros países. Esse modelo, embora genérico e vago, representou uma ruptura importante em relação às teorias tradicionais. Uma das suas implicações remete à intervenção dos poderes públicos na determinação da especialização: se uma parte dos fluxos internacionais pode ser explicada pelo esforço tecnológico, toda política que favorece a $\mathrm{P} \& \mathrm{D}$ pode influenciar o comércio entre as nações.

Na extensão da análise de Vernon, Katz (1992) observou que um grande número das atividades deslocadas gera produtos que não são totalmente semelhantes aos produtos de origem. Ele mostrou, para Argentina e Brasil, que muitos dos produtos exportados na década de 70 possuíam características próprias, representando tecnologias modificadas em relação aos produtos originais ${ }^{16}$. Essas mudanças, que são inovaçóes secundárias ou imitações inovadoras, são fatores de sucesso comercial em diferentes mercados, e são motivos de criação de vantagens competitivas. Sabe-se que o êxito de certas indústrias asiáticas no mercado internacional deveu-se à estratégia de importar e melhorar tecnologias. Terá que verificar, contudo, se tais possibilidades estão sendo estimuladas ou inibidas no contexto atual de mercados liberalizados.

John Dunning (1993) defendeu a idéia de que a propriedade de ativos diferenciados é um fator importante na explicação dos IDs. A propriedade exclusiva (ownership) de alguns ativos propicia à firma estrangeira vantagens sobre as firmas domésticas num determinado setor e motiva o ID. A firma estrangeira irá usar sua vantagem de propriedade se achar mais vantajoso internalizá-la do que vendê-la. Irá produzir no país de destino se aí existirem vantagens locacionais suficientes, e si o investimento externo se inserir em suas estratégias de longo prazo. Dunning apresenta quatro razóes para que

${ }^{16}$ Um exemplo disso para a década de 90 é o "carro popular", desenvolvido no Brasil. 
a firma invista no exterior: busca de recursos (resource-seeking), busca de mercados (market-seeking), busca de eficiência e busca de ativos estratégicos.

A articulação entre os ativos de conhecimento e os fatores locacionais está por trás da motivação de investimentos das FMs. Nos últimos anos, cresceu o seu investimento direto nos países não desenvolvidos, particularmente em busca de mercados ou em busca de recursos. A busca por mercados não é motivada apenas pelas necessidades de escoar produtos, mas, também, pela necessidade de estar presente nos mercados para defender estratégias concorrenciais. Essa busca de ativos estratégicos tende a mudar a natureza do fator locacional: as FMs se interessam pelos ativos estratégicos locacionais para facilitar a aplicação de seus ativos inovativos, que, eles, são moveis e sua aplicação é múltipla, flexível e relativamente barata.

Assim, o país hospedeiro pode ser um mercado e mesmo um espaço de produção, sem necessariamente ser um lócus de produção que possa radiar seus efeitos para a economia receptora e adensar sua malha produtiva e tecnológica. Se não gera efeitos produtivos e tecnológicos multiplicadores, o ID não pode participar realmente do desenvolvimento de um país e, tampouco, reduzir as assimetrias entre as economias que formam áreas de livre comércio.

As FMs concentram as atividades mais importantes, de pesquisa e inovação, nas unidades principais e nos pólos onde se radicam os seus fornecedores e clientes mais relevantes, descentralizando parcialmente as demais atividades. As capacitações inovativas e tecnológicas estão sujeitas a fortes economias dinâmicas de aprendizado e de especialização e, também, a economias externas, como o ambiente de pesquisa e a aproximação de pólos de inovação que reforçam a concentração nos centros mais desenvolvidos (COUTINHO, 2003).

Um estudo da Cepal (2005) sobre o destino setorial dos IDs revela que nenhuma inversão estrangeira na América Latina foi motivada pela busca de ativos tecnológicos. Nos últimos anos, a busca de mercados representou o maior motivo para os IDs nos países do Mercosul, apesar do maior interesse pelos recursos primários. O crescimento da demanda e a estabilidade econômica atraíram investimentos para as áreas de serviços, bens públicos e bens duráveis (CEPAL, 2005). São investimentos voltados para mercados 
domésticos oligopolizados que utilizam tecnologia importada e que não podem constituir especialidades.

Enfim, com a liberalização dos mercados, espera-se também uma convergência monetária e financeira. A expectativa é de que, simplesmente, a profunda globalização dos mercados financeiros acelere o nivelamento das taxas de juro, mesmo que subsistam diferenças nos níveis de spread. As taxas de juro são consideradas como custos homogêneos nas teorias predominantes nos estudos da economia internacional, ignorando os riscos de inadimplência que são muito mais elevados nas economias instáveis. Os riscos são ainda mais altos quando se trata de financiar atividades de inovação.

Paralelamente, o desenvolvimento da ciência e da tecnologia serve para aumentar a produtividade, criar novas variedades de produtos e garantir os rendimentos. A promessa de lucros extraordinários ajuda reduzir o custo do capital e a taxa de juro se torna, então, essencial para a formação de vantagens competitivas, sendo mais reduzida nos países onde há maior desenvolvimento tecnológico e científico.

As grandes disparidades no acesso ao financiamento e nos níveis de desenvolvimento sócio-econômico, em geral, estão na origem das grandes dificuldades encontradas nos processos de integração regional. As divergências são múltiplas e se encontram principalmente nas dimensóes dos mercados nacionais, no estado da infra-estrutura, no acesso à tecnologia e ao crédito, nas normas jurídicas e nas políticas macroeconômicas. A heterogeneidade das estruturas econômicas dos países promove uma situação de interdependência assimétrica, em que os países de pequeno tamanho dependem mais do mercado comum e, nele, se inserem de forma subalterna. As assimetrias, tão profundas, não podem ser removidas via mercado. Estudos empíricos mostram que a tendência à convergência é condicional, emitindo a hipótese de clubes de convergência, em que apenas países que reúnem certas características comuns podem homogeneizar os seus níveis de desenvolvimento via mercado.

\section{Investimento direto e formação do capital no MS}

Uma primeira noção das unióes aduaneiras consiste em adotar o quadro analítico estático da teoria neoclássica tradicional do comércio internacional. Essa abordagem ressalta o custo elevado de certos segmentos de produção 
que, mesmo sem vantagens comparativas no mercado internacional, abastecem mercados regionais sob a proteção de tarifas externas comuns (TECs). Ela se refere, em geral, ao conceito de criação e desvio de comércio, criado por Viner (1950). Na abordagem de Viner, como já foi observado, o desvio de comercio ocorre quando há substituição de uma importação do resto do mundo por uma importação do parceiro comercial, cujos custos unitários de produção são maiores, mas que se beneficia da TEC. A criação de comércio ocorre quando uma produção nacional é substituída, devido à remoção das barriras intrabloco, por uma importação de um parceiro cujos custos unitários são menores. Quando há mais desvio do que criação, podese dizer que a estrutura de especialização intrabloco esteja incompatível com uma integração competitiva no âmbito da economia mundial.

Yeats (1997) notou, para o período de 1988 a 1994, que os segmentos mais ativos no comércio intraregional são aqueles que realizam os resultados mais fracos no comércio mundial. A maioria desses segmentos beneficiava de tarifas alfandegárias em relação ao resto mundo mais elevadas do que a média das tarifas totais de importação. Isso sugere que a produção dos segmentos em questão se realiza a custos não competitivos a nível mundial.

Miotti, Quenan e Vinogradi (1998) e Yvars (2001) verificaram, respectivamente para Argentina e Brasil, as hipóteses de Yeats e descobriram que o número de segmentos caracterizados por desvio de comércio aumenta tanto na Argentina como no Brasil, no período 1986-1996. Machado e Cavalcanti (1999) encontraram um número de desvios maior do que de criaçóes, no caso do Brasil. Nagarajan (2000), com a mesma metodologia de Yeats, encontrou que, dentre os 30 produtos que tiveram no período 19901995 uma reorientação regional expressiva, 17 para Argentina e 20 para o Brasil são produtos que não pesam nas pautas de exportação extrabloco desses dois países.

Portanto, o comércio intramercosul não reflete as vantagens comparativas dos países membros, em geral mas, sim, as preferências tarifárias. São estas e não a maior competitividade das empresas que explicam a extraordinária expansão do comércio entre os países do MS. Elevar os fluxos entre os associados a taxas superiores às do comércio com o resto do mundo representa a própria finalidade da integração. $\mathrm{O}$ importante é saber em que 
medida este crescimento das transaçóes procede de uma criação ou de um desvio de comércio, em detrimento de países terceiros. Nos casos de desvio, a integração implica necessariamente em perdas para os consumidores associados, autorizando uma produção não competitiva.

Na medida em que, devido aos acordos negociados no seio da Organização Mundial de Comércio (OMC) e da Associação de Livre Comércio das Américas (Alca) e com outros blocos econômicos, como a União Européia, as importaçóes do MS passam a desfrutar de tarifas baixas no mercado sulamericano, as exportações intra-MS deverão cair e os produtores domésticos, hoje protegidos da maior capacidade competitiva dos estrangeiros pela TEC, sofrerão uma renovada e forte competição direta em seus próprios mercados domésticos.

Teoricamente, a expansão do comércio intramercosul, estimulada por mecanismos artificiais de acesso preferencial, alimenta a ineficiência alocativa dos fatores de produção e impede a especialização competitiva das economias. Isso representaria um empecilho à otimização produtiva, reduziria os ganhos multilaterais de comércio e entravaria a sua distribuição eqüitativa entre as naçóes. $\mathrm{O}$ argumento que se apóia na teoria das vantagens comparativas é que melhor seria se os países do MS importassem todo que não produzem com maior eficiência do resto do mundo e exportassem os bens para os quais possuem vantagens comparativas ${ }^{17}$. Este argumento, por um lado, ignora o fenômeno estrutural da deterioração dos termos cambiais e, por outro lado, pressupóe que a eficiência alocativa seja simplesmente dada pelos custos dos fatores de produção.

$\mathrm{Na}$ agroindústria e nos demais produtos de especialização do MS, os ganhos eventuais são relativamente limitados e não serão suficientes para saldar os déficits nos produtos mais elaborados. A elasticidade-preço da demanda dos produtos do MS nos mercados desenvolvidos é estruturalmente inferior àquela do MS para os produtos estrangeiros, o que perpetua a ameaça da deterioração dos termos cambiais.

Quanto à questão da alocação ótima dos recursos, deve-se ressaltar que

\footnotetext{
${ }^{17}$ Entre 1980 e 2000, portanto no período de maior abertura comercial, a América Latina registrou retração na sua participação nas exportações mundiais, inclusive nas exportações baseadas em recursos naturais, para as quais teria uma vantagem natural, segundo dados do Relatório da Unido de 2004.
} 
as decisões de investir extrapolam os limites da eficiência alocativa e dos parâmetros de custos fatoriais. O ambiente favorável ao investimento está definido por fenômenos como escala, inovação e demanda, os quais configuram as expectativas e estratégias empresariais. Assim, os fluxos comerciais que se desenvolveram dentro do MS na base de uma proteção seletiva podem sugerir uma ampliação do mercado que será capaz de estimular a articulação de uma nova estrutura produtiva eficiente e inovadora. Evidentemente, uma estrutura produtiva dinâmica e capaz de articular inovaçóes sucedidas exige um mínimo de densidade e diversidade da malha produtiva local, necessário para a realização e o aproveitamento de externalidades que não serão formadas com a especialização.

Pode-se argumentar que a abertura tem como efeito a atração do investimento direto, o qual irá avançar o processo de agregação de valor, adensar a malha industrial local e enraizá-la mais profundamente, tornandoa mais competitiva. Com isso, os países que recebem investimentos diretos aumentam suas exportações, assim como a sua participação na criação global de riquezas ${ }^{18}$. Porém, devido às razoes examinadas, a penetração do capital externo poderá tender a atuar mais sob a forma de licenciamentos, venda de patentes e marcas do que sob a forma de investimento. De fato, as novas condiçóes de produção e de comunicação estimulam cada vez mais as multinacionais a não produzir localmente. Elas tenderiam a reforçar as suas posiçóes industriais a partir do país de origem, onde podem aproveitar economias de escala e de escopo.

Os trabalhos que procuram determinar a influência dos IDs sobre a taxa de crescimento do PIB ou analisar a causalidade reversa entre essas duas variáveis concluem, em geral, que esses investimentos têm efeito positivo sobre o crescimento econômico, dependendo de uma séries de condiçôes: o estoque de capital humano disponível na economia hospedeira (BORENSTEIN, GREGÓRIO, LEE, 1995); a possibilidade de atrair atividades complementares (MELLO, 1999), o nível de escolaridade do

\footnotetext{
${ }^{18}$ A América Latina é a região que mais abriu o seu mercado dentre os países não desenvolvidos, o que não impediu que a participação de suas exportações nos mercados desenvolvidos caísse de 17 para 8\%, entre 1980 e 2000, Segundo o Relatório Anual da Unido, de 2004. Ainda, no conjunto dos países periféricos, os que mais se capacitaram em alta tecnologia, entre 1980 e 2000, são Taiwan e Coréia do Sul, duas economias que restringiram a entrada de investimentos estrangeiros no período.
} 
país receptor (LIPSEY, 2000); o seu grau de abertura (NAIR-REICHERT, WEINHOLD, 2001); a existência de economias de aglomeração (CAMPOS, KINOSHITA, 2003); a flexibilidade na legislação sobre ingresso de capital (GARIBALDI, 2001). Ainda, outros enfatizam as condiçóes de estabilidade econômica, de infra-estrutura, de níveis de renda, de previsão de crescimento e de quadro institucional. As condiçôes são tão importantes que somente os países mais desenvolvidos as possuem, auferindo lhes uma situação privilegiada para atrair investimentos que contribuam de fato para o crescimento.

Vale notar que há diferenças substanciais entre os fluxos que envolvem apenas países desenvolvidos - tanto como países de origem como hospedeiros - e aqueles em que os hospedeiros são países em desenvolvimento. Segundo a classificação de Dunning (2002), no primeiro caso ocorrem investimentos do tipo procura de ativos estratégicos, em que o ID é representado por uma operação de fusão e aquisição, e do tipo procura de eficiência horizontal. Já no segundo caso, os investimentos são caracterizados por procura de mercados, de recursos ou de eficiência horizontal.

Os dados da Cepal (2007) confirmam, para América Latina, essa caracterização feita por Dunning, ao mostrar que os investimentos estrangeiros na região buscam essencialmente recursos naturais e mercados, nos segmentos de energia, minério, serviços, alimentos, química, eletrônica e automotores. Eles revelam uma queda relativa da presença de empresas transnacionais na América Latina, em todos os setores. No setor primário, o seu faturamento caiu de 17 para 13\%, entre 2000 e 2005. Na indústria, as empresa estrangeiras registraram uma queda em suas vendas no mercado regional, de 58 para $38 \%$ e, no setor de serviços, passaram de 38 a 23\%, no mesmo intervalo. Essas empresas também perderam participação nas exportaçóes da região. Por uma grande parte, todavia, essa contração das exportaçóes relativas das multinacionais a partir dos países não desenvolvidos deveu-se ao forte crescimento dos preços das commodities, onde as empresas públicas da América Latina ocupam maior espaço. Os mesmos dados apontam uma queda total do IDs na América Latina e Caribe, entre o período 1997-2001 e o período 2002-2006, passando de uma média anual de 77 bilhóes de dólares para 61 bilhões de dólares. O seu nível vem se recuperando paulatinamente entre os anos 2005 e 2006 (US\$ 72 bilhóes). 
Como pode se ver na Tabela 1, essa recuperação dos IDs na América Latina inclui os países do Mercosul, para os quais os dados da Cepal mostram uma queda absoluta contínua, desde 1998, passando de uma média anual de US\$ 9,4 bilhôes, no período 1992-1996, para 2 bilhóes, no período 2002-2006 ${ }^{19}$. Não obstante ter havido, na década de 1990, um grande fluxo de IDs para países do Mercosul, devido essencialmente às privatizaçôes, a participação da região nos IDs mundiais caiu e a sua importância no Pib permaneceu igual, em torno de 3\%. Dados da Abeceb (2006) evidenciam a queda dos IDs no MS a partir de 2000, mostrando que em 2003 o seu montante chegou à chifra de 12 bilhóes, o que representa o quarto do que foi recebido em 1999.

Tabela 1 - IDs no Mercosul 1992-2006 (média anual, em milhôes de dólares)

\begin{tabular}{|l|c|c|c|c|c|}
\hline & $\mathbf{1 9 9 2 - 1 9 9 6}$ & $\mathbf{1 9 9 7 - 2 0 0 1}$ & $\mathbf{2 0 0 2 - 2 0 0 6}$ & $\mathbf{2 0 0 5}$ & $\mathbf{2 0 0 6}$ \\
\hline Argentina & 4.683 & 10.605 & 3.640 & 5.008 & 4.909 \\
& $(1.196)$ & $(1,754)$ & $(749)$ & $(1.151)$ & $(2,008)$ \\
\hline Brasil & 4.497 & 27.075 & 15.746 & 15.067 & 18.782 \\
& $(516)$ & $(1.095)$ & $(8.461)$ & $(2.517)$ & $(\mathbf{2 8 . 2 0 2})$ \\
\hline Paraguai & 0.116 & 172 & 51 & 75 & 117 \\
\hline Uruguai & 110 & 219 & 633 & 847 & 1.374 \\
\hline Total & 9.406 & 38.071 & 20.070 & 20.997 & 24.182 \\
\hline
\end{tabular}

FONTE: Cepal (2007)

Os valores entre parênteses indicam o ID do país no estrangeiro, incluindo os investimentos intramercosul e são da Abeceb

O MS recebe pouco capital para seu setor industrial e tampouco nos segmentos de alta tecnologia, sendo mais atrativo para os investimentos nas atividades de base. Estas poderão, sim, aprofundar os processos de transformação e de criação de valor nessas áreas, porém não é na especialização básica que se garante a agregação continuada de valor e que se assegure uma inserção global ativa.

Entre os anos cinqüenta e setenta, o ID na América Latina era motivado essencialmente pela necessidade de contornar as barreiras que protegiam os mercados nacionais e, dentro destes, produzir o que não se podia ou era difícil exportar. Essa motivação será minimizada quando as tarifas serão nulas e poderá haver maior redução da participação do investimento estrangeiro na

${ }^{19} \mathrm{Em} 2006$, fato inédito, o ID líquido do Brasil ficou negativo, com mais de 9 bilhões de dólares (ABCEB, 2006) 
formação do capital regional.

Quanto aos IDs intra-Ms, a sua participação nos IDs totais na região é muito baixa, embora venha crescendo nos últimos anos como parte do processo de internacionalizaçáo das empresas locais e da necessidade estratégica de estabelecer presença nos mercados vizinhos ${ }^{20}$. Nos anos de 1990, o processo de privatizaçóes no Brasil havia gerado boas oportunidades de investimento argentino. Algumas empresas portenhas participaram em consórcios que obtiveram concessão para operar redes viárias e empresas elétricas no Brasil. Outras empresas argentinas investiram no Brasil em segmentos como alimentos, montagem de equipamentos, telecomunicaçóes e petroquímica. Esses investimentos se elevaram a 1,2 bilhão de dólares, entre 1997 e 2000, segundo dados do Banco Central da Argentina (2004).

A partir da crise argentina, logo no início da década de 2000, o fluxo líquido de IDs desse país com o Brasil se inverteu. De 2001 a 2006, o Brasil investiu quase 6 bilhóes de dólares no país vizinho, em setores como petróleo, carnes, cerveja, cimento e têxtil. (BBC Brasil, 14/12/2007). O Brasil já é o terceiro país no ranking dos investidores diretos na Argentina, perdendo apenas pelos EUA e Espanha. Em 2006, as empresas brasileiras investiram 1,8 bilhão de dólares (1 bilhão da Petrobrás) na Argentina, representando, no entanto, apenas $6,4 \%$ do conjunto dos IDs brasileiros no exterior ${ }^{21}$.

Iglesias e Veiga (2002) retrataram o perfil dos IDs brasileiras no estrangeiro, inexpressivos ${ }^{22}$ e concentrados em poucas atividades que, excluindo aqueles da Petrobrás, dispensam investimentos em pesquisa, marca, inovação e outros conteúdos em ciência e informação. A motivação desses investimentos está basicamente na busca de mercados e no acesso a recursos naturais. Alguns dos investimentos estão nos bens de capital e bens intermediários diferenciados ou bens de consumo que requerem despesas de apóio à exportação. Nos bens duráveis de consumo, o investimento brasileiro é muito baixo, devido à dominação quase absoluta do setor brasileiro desses bens pelo capital

\footnotetext{
${ }^{20} \mathrm{O}$ investimento exterior nem sempre é uma escolha. A não participação no ID pode implicar perdas para as empresas domésticas.

${ }^{21}$ Nesse ano, o investimento brasileiro no exterior registrou um recorde de 28 bilhões de dólares. Mas, em termos de PIB, continua um dos mais baixos do mundo.

${ }^{22}$ A pouca importância dos IDs se explica, parcialmente, pelo alto custo do capital e pela distância dos principais eixos comerciais.
} 
estrangeiro (COUTINHO, 2003).

\section{Desequilíbrios econômicos e obstáculos à formação do Mercosul}

As Tabelas 2 e 3 mostram as desproporçóes das economias que formam o Mercosul, revelando o reduzidíssimo peso do Paraguai e Uruguai no produto total, na formação do capital, no valor agregado industrial, nos investimentos, nas exportaçóes, etc. Deve-se acrescentar a isso as disparidades em termos de tecnologia, produtividade, densidade das malhas produtivas, gastos governamentais, que, todas tendem a prejudicar os países menos desenvolvidos, reforçando suas desvantagens iniciais.

Tabela 2 - População Mercosul, milhóes (2005)

\begin{tabular}{|l|c|c|c|c|c|} 
& Argentina & Brasil & Paraguai & Uruguai & Total \\
\hline Habitantes & 38.747 & 168.404 & 6.158 & 3.463 & 216.772 \\
\hline - Participação (\%) & 17,87 & 77,69 & 2,8 & 1,6 & 100 \\
\hline
\end{tabular}

FONTE: Elaboração do autor, a partir dos dados do relatório do Banco Mundial (2005)

Tabela 3 - Macrodados econômicos Mercosul, US\$ milhóes, preços constantes de 2004

\begin{tabular}{|l|c|c|c|c|c|}
\hline & Argentina & Brasil & Paraguai & Uruguai & Total \\
\hline Produto Interno Bruto & 129.735 & 491.857 & 6.040 & 11.182 & 638.814 \\
\hline - Participação (\%) & 20,31 & 77,00 & 0,94 & 1,75 & 100 \\
\hline PIB/Habitantes (US\$) & 7518 & 3541 & 1289 & 5747 & ---- \\
\hline Valor Agregado Industrial & 50.239 & 135.092 & 1.138 & 3.412 & 189.881 \\
\hline - Participação (\%) & 26,46 & 71,15 & 0,67 & 1,78 & 100 \\
\hline Formaçáo Bruta do Capital Fixo & 49.742 & 151.833 & 2.668 & 2.402 & 206.645 \\
\hline - Participaçãa (\%) & 24,07 & 73,47 & 1,29 & 1,16 & 100 \\
\hline Exportaçóes & 37.564 & 99.006 & 3.007 & 4.199 & 143.776 \\
\hline - Participação (\%) & 26,12 & 68,86 & 2,09 & 2,92 & 100 \\
\hline Importaçáes & 27.133 & 73.078 & 3.354 & 3.778 & 107.343 \\
\hline - Participação (\%) & 25,27 & 68,07 & 3,12 & 3,51 & 100 \\
\hline Invest. estrangeiro direto líquido & 3.993 & 8.695 & 0.064 & 0.299 & 13.051 \\
\hline - Participação (\%) & 30,59 & 66,62 & 0,49 & 2,29 & 100 \\
\hline
\end{tabular}

FONTE: Elaboraçáo do autor, a partir dos dados do FMI

(World Economic Outlook, 2005) e da Cepal (2005)

Pelo tamanho, o Brasil possui uma vantagem estrutural que lhe confira 
uma das maiores vantagens no comércio internacional, que é o rendimento de escala. Em linhas gerais, esse país consolidou sua posição hegemônica na indústria, enquanto que os países menores (Uruguai e Paraguai) assistiram, desde 1990, ao aumento do peso do setor primário. Entre 1994 e 2004, Argentina, Uruguai e Paraguai perderam importância no total da indústria do MS. O Brasil, de 2000 a 2005 ganhou 7 pontos percentuais na sua participação nas exportações da região, chegando a $72.4 \%$, ao passo que Argentina perdeu muito terreno, passando a representar $24,5 \%$, em vez de $31,6 \%$ no ano de 2000 (ABCEB, 2007). Uruguai seguiu perdendo posição e o Paraguai manteve a sua participação.

O Brasil é o maior mercado para as exportaçóes dos demais países do MS, com 90\% do mercado regional. As importações brasileiras do MS possuem baixo valor unitário, enquanto que suas exportaçóes dentro do bloco apresentam um maior valor agregado, como automóveis, celulares, máquinas, plástico, etc.

De 1990 a 2004, a participação do setor agropecuário cresceu em todos os países do MS, mas de forma mais acentuada no Uruguai e Paraguai. Nesses países, o setor em questáo passou de 11 a 12,6\% e de 27,5 a 31,4\% dos respectivos produtos internos. No Brasil, no mesmo período, a agropecuária avançou de 7 para 8,2\%. No mesmo tempo, o comercio intra-Ms de produtos agrícolas tendeu a se contrair, sobretudo depois que os países membros decidiram substituir importaçóes, como no caso do Brasil que passou a se auto-abastecer em arroz e trigo. È o caso também dos demais países do bloco que passaram a produzir soja para aproveitar o surto dos preços no mercado mundial. A partir disso, foi traçado um movimento em que os países da regiāo reorientam suas exportaçóes para fora do MS. Essa reorientação teve início na crise do real no final de 1999.

Portanto, as disparidades não se atenuaram durante todos esses anos de união tarifária. As desigualdades iniciais se aprofundaram, sobretudo depois das desvalorizaçóes cambiais no Brasil e na Argentina, o que dificultou sobremaneira o processo de integração. As cadeias produtivas regionais, por exemplo, não podem se integrar quando as taxas de câmbio são instáveis e os desequilíbrios externos persistentes. A distorção cambial deturpa os preços relativos e mantém os mercados segmentados nos modelos nacionais, 
reduzindo o impacto da integração em termos de ganhos de escala e de atração de investimentos. A integração no caso do MS, por estar limitada à unificação das tarifas alfandegárias, estimula as oscilações nas taxas de câmbio e aumenta os custos associados aos desvios de comércio.

Nas fases de recessão, as transaçóes comerciais se contraem de forma rápida e desproporcional, e a sua recuperação é lenta, como mostrou a evolução do comércio entre os países do MS durante e depois dos choques que atingiram o Brasil e a Argentina no início da década atual23. Quando as depressões são acompanhadas por desvalorizações cambiais, transformações drásticas podem ser provocadas nos níveis relativos de competitividade entre os associados. Os efeitos cambiais sobre o comércio regional são mais importantes e mais imediatos do que àqueles que podem ser gerados, seja pela queda negociada das tarifas aduaneiras, seja pelos ganhos reais de produtividade.

As crises econômicas realçam os conflitos potenciais entre os países associados por acordos tarifários e desencadeiam reaçóes protecionistas não tarifárias (barreiras sanitárias, normas técnicas, etc.), exigindo medidas extras, não previstas pelas normas comunitárias. Quando as crises são recorrentes, a credibilidade nos acordos desmorona e solapa toda aposta que se possa fazer no sucesso da integração.

Nos países que formam o MS, as indústrias nacionais ainda operam em escalas insuficientes de mercado. A remoção das barreiras comerciais pode, nessa situação, representar uma possibilidade de ampliar o mercado, reduzir os custos de produção e abrir perspectivas para a especialização intraindustrial. Mas o grau elevado das exceçóes às regras estabelecidas e a multiplicidade das normas e sua complexidade são obstáculos que aumentam os custos das transaçóes e inibem os investimentos. Os direitos específicos e compensatórios, os regimes especiais, a exoneração unilateral das tarifas externas e outras tantas práticas de defesa comercial colocam em questão os próprios princípios da união aduaneira e suscitam o descrédito do MS. Essas inconsistências tornam difícil aos investidores avaliar os níveis de abertura efetiva e, conseqüentemente, tomar as decisóes adequadas.

A dificuldade em respeitar as normas está diretamente associada à

\footnotetext{
${ }^{23}$ Entre 1999 e 2003, o comércio intra-MS passou de 14,1\% para 7,8\% do total exportado pelos países membros, em razão dos profundos ajustamentos fiscais e monetários provocados pela crise externa. Depois da secunda metade de 2003, o crescimento das transações regionais foi retomado a um ritmo muito lento.
} 
existência de inúmeros setores sensíveis, que não conseguem encontrar formas ativas de inserção e integração regional e que são importantes para as economias nacionais. Ela é prolongada em razão da ausência de mecanismos de absorção dos conflitos de interesses e da falta de uma coordenação nas políticas macroeconômicas.

Em dezembro de 2003, os países do MS estabeleceram um "programa de trabalho para os anos 2004-2006", no qual foram incluídas questóes relativas à cooperação cientifica e tecnológica e à integração energética. Mas, as discussóes formais permaneceram concentradas no objetivo de eliminar os obstáculos à união tarifária. As dificuldades encontradas para consolidar o sistema de TEC residem, em grande parte, nos desequilíbrios econômicos regionais. A estrutura alfandegária adotada penaliza os pequenos associados, pois, tendo bases produtivas mais restritivas, os seus níveis de proteção efetiva ficam consideravelmente reduzidos. Ainda, os países menos desenvolvidos, Uruguai e Paraguai, se encontram desfavorecidos em diferentes recursos, tais como o financiamento do investimento e a subvenção da indústria. Esses países sofreram duramente os efeitos das últimas crises cambiais dos países vizinhos e arcaram indiretamente com uma parte do ônus.

As divergências macroeconômicas, aliadas às políticas de subsídios e promoção das exportaçóes nos países mais desenvolvidos do bloco agravam os problemas provocados pela disparidade original dos níveis de competitividade. A falta de uma integração na base de concessóes recíprocas, a inexistência de programas de cooperação para reduzir os desequilíbrios e o déficit institucional são alguns dos maiores obstáculos à tendência a uma real convergência no MS.

Todavia, a constituição do Fundo Social em 2006 deu um novo ânimo às negociaçóes de integração, sobretudo ao coincidir com um aumento significativo (20\%) nos fluxos comerciais intrabloco no mesmo ano. Um fundo social comum pode significar que a constituição da União deixe de ser uma iniciativa restrita aos governos para incluir a sociedade civil. Um outro passo importante está se dando com a formação de um sistema de pagamentos com moedas locais no comércio bilateral. Vale assinalar também as iniciativas do Brasil de reduzir as tarifas sobre as importaçóes do bloco e abaixar os índices requeridos de nacionalidade dos produtos oriundos do 
Paraguai e Uruguai.

A criação do Fundo para a Convergência Estrutural é uma outra iniciativa que pode redinamizar o processo de integração, sendo um elemento essencial para, junto com o Banco do Mercosur, financiar projetos de infra-estrutura e, assim, reduzir as assimetrias entre os sócios. Ainda, a necessidade de uma cooperação mais avançada na questão energética aumenta as chances de, finalmente, consolidar a integração desejada.

A união dos assimétricos depende do apoio dos mais fortes, como isso ocorre na União Européia. O êxito da integração de economias desiguais se dá somente através de uma vontade política comum que vai além das iniciativas comerciais e que contém nela um vasto programa de apóio às regióes atrasadas, sobretudo através dos investimentos em infra-estrutura, de modo a reduzir os desequilíbrios.

Porém, sem condiçóes financeiras e com dificuldades domésticas, os governos não conseguem acomodar as divergências e reduzir as disparidades. Os países do MS não investem na infra-estrutura desde o final da década de setenta. O boom das privatizaçóes e os investimentos diretos na energia e nas telecomunicaçóes dos anos noventa não geram, fora a telefonia celular, a difusão esperada de um grande número de utilidades públicas para a maioria da população. As camadas pobres, que já eram esbulhadas dos serviços tradicionais, se vêem novamente excluídas dos serviços modernos. Essas duas dimensóes de heterogeneidade das estruturas domésticas de mercado se associam às desigualdades regionais para ampliar os desequilíbrios.

Em todos os países do MS, as disparidades entre o setor exportador e o não exportador se aprofundem e a produtividade permanece baixa na agricultura e nos serviços. No Brasil, a produtividade total cresceu apenas $1,5 \%$, entre 1991 e 2005 . Reduziu-se a diferença nos níveis de produtividade entre a indústria e a agricultura brasileiras, mas aquela entre a indústria e os serviços foi incrementada. Entre 1991 e 2003, as taxas de desemprego aumentaram significativamente em todos os países do MS, particularmente na Argentina e no Brasil.

A participação do salário no PIB do MS se contraiu e a baixa produtividade na produção de alimentos para o consumo doméstico tende a contrair o salário real da população mais pobre. As tarifas públicas aumentaram, afetando 
duramente os baixos salários. O índice de Geni subiu e, na Argentina e no Paraguai, a proporção dos pobres na população total aumentou. Os países sul-americanos, como todos os da América latina, se tornaram fonte de imigração maciça para os Estados Unidos.

Sem uma coordenação econômica real, os elementos de convergência dos países do MS se limitam àqueles obtidos pela aplicação de planos semelhantes de ajustamento externo, inserindo-os num modelo de acumulação dominado pelos setores de exportação. As resultantes taxas de crescimento econômico são baixas, entre 3 e $5 \%$, e os seus ciclos são de curta duração, acompanhando os movimentos internacionais do capital e dos preços das commodities. Os regimes de câmbio são flutuantes e as disciplinas fiscais produzem excedentes primários elevados, entre 3 e 5\% dos respectivos PIBs. As taxas de inflação estão baixas, os excedentes comerciais relativamente elevados e os coeficientes de endividamento similares.

\section{Considerações finais}

Os acordos formais não implicam necessariamente numa integração econômica. Aliás, um movimento de liberalização unilateral ou multilateral pode ser suficiente (como isso ocorreu no processo de industrialização do sudeste asiático) para gerar uma integração que é, antes de tudo, conseqüência espontânea das relaçóes comerciais internacionais. Todavia, o caráter espontâneo de certas formas de regionalização permite apenas uma cooperação relativamente limitada, sugerindo a necessidade de acordos voluntários e formais para aprofundar a integração e aumentar a sua eficiência. Os acordos regionais de integração formal se destacam por seus efeitos discriminatórios que levam à criação de blocos econômicos, cujo êxito exige esforços que não se limitam aos aspectos comerciais e que devem promover processos de convergência produtiva e institucional.

Uma política de integração regional nesse sentido deve buscar a garantia de igualdades na concorrência por investimentos. Dessa forma, seu enfoque deve estar na criação de atividades competitivas e sustentáveis, através de investimentos em infra-estrutura, capital humano e tecnologia. O êxito de tal política depende fundamentalmente da capacidade de coordenar esforços, administrar conflitos e obter recursos. 
Os desequilíbrios nas dimensóes econômicas em termos de mercado, investimento e tecnologia se revelam como fortes obstáculos à integração, mostrando o caráter insuficiente de acordos meramente comerciais. A ausência de uma vontade política baseada nas concessóes recíprocas e no interesse em promover e estender as oportunidades de desenvolvimento para os parceiros menos competitivos, aliada à falta de um quadro institucional na altura de zelar sobre o respeito dos acordos são os principais obstáculos à formação do Mercosul. A experiência da União Européia constitui-se numa prova de que a redução das disparidades regionais é uma condição necessária ao êxito da integração. Ela mostra que a expansão do comércio e a subscrição dos acordos de cooperação são dois movimentos complementares. 


\section{Referências bibliográficas}

ABCEB. 15 anos de Mercosul: avaliación y perspectivas. Mar. 2006. Disponível em: http://www.abceb.com.

ANDERSON, James. E.; VAN WINCOOP, Eric. Gravity with Gravitas: o solution to the Border Puzzle. American Economic Review, v. 93, n. 1, 2003.

BALDWIN, E. Robert. Trade policies in developed countries. In: JONES, Ronald W.; KENEN, Peter B. (Eds.). Handbook of international economic. Amsterdã: 1984. Volume 1.

BANCO CENTRAL DE LA REPÚBLICA ARGENTINA. Informe, Buenos Aires, 2004.

BANCO MUNDIAL. Relatório, 2005.

BORENSTEIN, Eduardo; GREGORIO, José de; LEE, Jong Wha. How does foreign direct investment affect economic growth? NBER Working Paper, Cambridge, MA, n. 5.057, 1995.

BRÜLHART, Marius. Commerce et specialisation geographique dans L'Union Européenne. Économie Internationale, n. 63, 1996.

BUCKLEY, Peter J.; GHAURI, Pervez N. The internationalization of the firm: a reader. London: International Thomson Business Press, 1991.

CAMPOS, Nauro F; KINOSHITA, Yuko. Why does FDI go where it goes? New evidence from the transition economies. IMF Working Paper, IMF Institute, Nov. 2003.

CAVES, Richard. E., International corporations: the industrial economics of foreign investment. Economica, London, Blackwell Publishing, v. 38, Feb. 1971.

CEPAL. Balance preliminary de las economias de América latina y Caribe. Santiago de Chile: 2007.

Las inversiones extranjeira en América latina y el Caribe. Santiago de Chile: abril, 2005. 
- Estadístico Anuário da América latina e Caribe. Santiago de Chile: 2005.

CHUANG, Yih-Chyi. Learning by doing, the technology gap, and growth. International Quarterly Journal of Economics, v. 106, n. 2, p. 326-406, 1998.

CORDEN, Warner Max. The theory of protection. Oxford: Clarendon Press, 1971.

COUTINHO, Luciano. Internacionalização das empresas brasileiras. Folha de São Paulo, Caderno Dinheiro, 05 ago. 2003.

DUNNING, John H. Multinational enterprise and the global economy. Wokinghan: Addison-Wesley, 1993.

. Determinants of foreign direct investment: globalization induced changes and the role of FDI policies. Annual Bank Conference on Development Economics, 2002.

FMI. World Economic Outlook, 2005.

FREENSTRA, Robert; MARKUSEN, James; ROSE, Andrew. Using the gravity equation to differentiate among alternative theories of trade. Sept. 2000. Disponível em: http://faculty.haas.berkeley.edu/arose/FMR.

FERREIRA, Graça Enes. A teoria da integração económica internacional e o modelo de integraçáo no espaço económico europeu. Porto: Legis Editora, 1997.

FRANKEL, Jeffrey. A. Regional trading blocs in the world economic system. Institute for International Economics, Washington, DC, 1997.

. The regionalization of the world economy. Chicago: The University of Chicago Press, 1998.

FRANKEL, Jeffrey; ROMER, David. Trade and growth: an empirical investigation. NBER Working Paper, n. 5.476, 1996.

FUJITA, Masahisa; KRUGMANN, Paul; VENABLES, Anthony J. The spatial economy: cities, regions and international trade. Cambridge/Mass: MIT Press, 1999. 
GARIBALDI, Pietro. What moves capital to transition economies? IMF Staff Papers, International Monetary Found, Special Issue, v. 48, 2001.

GEHRELS, Franz. Customs Union from Single-Country Viewpoint. Review of Economic Studies, 1956.

GRAHAM, Edward. Strategic management and transnational firm behaviour: a formal approach. In: PITTELIS, Christos.; SUGDEN, Roger. The nature of the transnational firm. 2nd ed. London: Routledge, 2000.

GREENAWAY, David; HINE, Robert; MILNER, Chris R. Vertical and horizontal intraindustry trade: a cross insustry analysis for the United Kingdon. The Economic Journal, v. 105, p. 1504-1518, 1995.

GREGORY, T. E. Tariff: a study in method. London: Grifin, 1921.

GROSSMAN, Gene; HELPMAN, Elhanan. Trade, innovation and growth. American EconomicReview, Papers and Proceedings, v. 80, n. 2, p. 86-91, 1990.

HABERLER, Gottfried Von. Some reflections on the present situation of business cycles theory. The Review of Economic Statistics, v. 18, n. 1, p. 1-7, Feb. 1936.

. The theory of international trade. Augustus M Kelley Pubs, 1937.

HARFI, M.; MONTET, C. ; OULMANE, N. Commerce Intrabranche, Différenciation des Produits et Ajustement en termes d'Emploi en France. In : de Melo et Guillamont, 1997.

HARRISON, Ann. Openness and growth: a time series, cross-country analysis for developing countries. Journal of Development Economics, v. 48, p. 419$447,1996$.

HYMER, Stephen. The international operations of national firms: a study of direct foreign investment. MIT: MIT Press, Ph.D. Dissertation, 1976.

IGLESIAS, Roberto M.; VEIGA, Pedro M. Promoção das exportações via internacionalização de firmas de capital brasileiro, In: PINHEIRO, A. $O$ desafio das exportaçôes. Rio de Janeiro: BNDES, 2002. 
IPEA. Determinantes dos investimentos diretos externos em países em desenvolvimento. Texto para Discussão, mar. 2004.

IZERROUGENE, Bouzid. Instabilidade das finanças internacionais $e$ vulnerabilidade das economias periféricas. Salvador: FCE/FBA, 2000.

KATZ, Jane. Regional evolution. Brooking Papers on Economic Activity, v. 1, 1992.

KINDLEBERGER, Charles P. American business abroad: six lectures on direct investment. New Heaven, Yale University Press, 1969.

KOSACOFF, Bernardo; CAMPANARIO, Sebastián. La revalorización de las materias primas y su efecto em América Latina. CEPAL, mar. 2007.

KRUGMAN, Paul R. Target industrial policies: theory and evidence, protectionist threat to world welfare. Amsterdã: 1987.

. The move toward free trade zones. Economic Review, Federal Bank of Kansas City nov./dez. 1991.

Increasing returns and economic geography. Journal of Political Economy, v. 9, n. 3, p. 483-499, 1991.

KUWAYAMA, Mikio; DURAN LIMA, José E. A calidad de la insercion internacional de América latina y el Caribe en el comercio mundial. Santiago de Chile: 2003. Disponível em http//:www,eclac.org?publicaciones/ $\mathrm{xml} / 9 / 1240$.

LACERDA, Antonio Correa de. Globalização e investimento estrangeiro no Brasil. São Paulo: Saraiva, 2004.

LANCASTER, Kelvin. Variety, equity and efficiency. New York: Columbia University Press, 1978.

LEE, Jong-Wha. International trade, distortions, and long-run economic growth. IMF Staff Papers, v. 40, n. 2, p. 299-328, 1993.

LIPIETZ, Alain; BENKO, Georges (Org.). As regióes ganhadoras. Distritos e redes. Os novos paradigmas da geografia econômica. Oeiras: Celta Editora. 1994 (1. ed. Francesa de 1992). 
LIPSEY, Robert E. Inward FDI and economic growth in developing countries. Transnational Corporations, v. 9, n. 1, Apr. 2000.

MANKIW, Gregory; ROMER, David; WEILL, David. A contribution to the empirics of economic growth. The Quarterly Journal of Economics, v. 107, n. 2, p. 407-437, 1992.

MARKUSEN, James R.; VENABLES, Anthony J. Multinational firms and the new trade theory. NBER Working Paper, n. 5036, Feb. 1995.

MEADE, James Edward. The theory of customs unions. Amsterdam: North Holland Publishing Company, 1955.

MELLO, Luiz R. de. Foreign direct investment-led growth: evidence from time series and panel data. Oxford Economic Papers, v. 51, p. 199-151, 1999.

MELO, Jaime de; PANAGARIYA, Arvind. New dimensions in regional integration. New York, USA: Cambridge University Press, 1993.

MIOTTI, Luis; QUENAN, Carlos; VINOGRAD, Carlos. Spécialisation internationale et integration régionale: l'Argentine et le Mercosur. Economie Internationale, n. 74, 1998.

MUNDELL Robert A. Transport costs in international trade theory. Canadian Journal of Economics and Political Science, 23, 331-348, Aug. 1957.

NAGARAJAN, Nigel. La evidencia sobre el desvio de comercio en el Mercosur. Integracion y Comércio, v. 4, 2000.

NAIR-REICHEIT, U.; WEINHOLD, D. Causality tests for cross-country panels: new look at FDI and economic growth in developing countries. Oxford Bulletin of Economics and Statistics, v. 63, n. 2, p. 151-171, 2001.

. Causality tests for cross-country panels: new look at FDI and economic growth in developing countries. Barcelona: Oikos, 1971 (Orig. 1933).

OHLIN, Bertil. Interregional and international trade. Cambridge: Harvard University Press, 1933.

PORTER, Michael E. Vantagem competitiva das naçôes. Rio de Janeiro: Campus, 1990. 
. Competitive advantage. New York: Free Press, 1985.

POSNER, Michael. International trade and technical change. Oxford Economic Paper, Oct. 1961.

RODRIGUEZ, Francisco; RODRIK, Dani. Trade policy and economic growth: a skeptic's guide to the cross-national evidence. NBER Working Paper, n. 7.081, 1999.

ROGOFF, Kenneth. An open letter to Joseph Stiglitz. IMF External Relations Department: 2002. Disponível em http://www.imf.org/external/np/ vc/2002/070202.

ROMER, Paul M. The origins of endogenous growth. Journal of Economic Perspectives, v. 8, n. 1, p. 3-22, winter, 1994.

SÁ PORTO, Paulo C. de. Mercosul and regional development in Brasil: a gravity model approach. Revista de Estudos Econômicos, São Paulo, v. 32, n. $1,2002$.

SIROËN, Jean-Marc. La specialisation international et les gains de l'échange dans la theorie de la concurrence monopolistique. Revue d'Economie Industrielle, n. 55, 1991.

La theorie de l'échange international en concurrence monopolistique: une comparaison des modeles. Revue Économique, v. 39, n. 3, mai. 1988.

UNCTAD. World Investment Report. New York: 2005.

UNIDO. United Nations Industrial Development Organization. Relatório. 2004.

VENABLES, Anthony. Equilibrium locations of vertically linked industries. International Economic Review, v. 37, n. 2, p. 341-359, 1996.

VERNON, Raymond. International investment and international trade in the product cycle. Quarterly Journal of Economics, v. 80, May. 1966.

VINER, Jacob. The customs union issue. New York: Camegie Endowment for International Peace, 1950. 
YEATS, Alexander. Does Mercosur's trade performance raise concerns about the effects of regional trade arrangement? Policy Research Woorking Paper, World Bank, 1729, Feb. 1997.

YOUNG, Alwyn. Learning by doing and the dynamics effects of international trade. The Quarterly Journal of Economics, v. 106, n. 2, 1991.

YVARS, Bernard. Économie de l'Union Européenne. Paris: Ed. Dunod, 2001. 